\title{
Macrocyclic Carbon Suboxide Oligomers as Potent Inhibitors of the Na,K-ATPase
}

\author{
ROBERT STIMAC, ${ }^{a}$ FRANZ KEREK, ${ }^{b}$ AND HANS-JÜRGEN APELL ${ }^{a}$ \\ ${ }^{a}$ Department of Biology, University of Konstanz, 78457 Konstanz, Germany \\ ${ }^{b}$ MPI for Biochemistry, 82152 Martinsried, Germany
}

\begin{abstract}
KEYwoRDS: macrocyclic carbon suboxide (MCS); sodium pump; inhibition; partial reactions
\end{abstract}

A new class of $\mathrm{Na}, \mathrm{K}$-ATPase inhibitors are macrocyclic carbon suboxide (MCS) factors, which are cyclo-oligomers of $\mathrm{C}_{3} \mathrm{O}_{2} \cdot{ }^{1}$ They inhibit the enzymatic activity with half-inhibiting concentrations of $10 \mathrm{nM}, 100$-fold lower than ouabain. In contrast to cardiac steroids, they hardly discriminate between rat and rabbit enzyme. Our preparation consists of structurally different MCS factors and their complex with $\mathrm{Na}^{+}$ions. The composition of this equilibrium mixture and its activity can be modulated by acids and bases.

Experiments with the fluorescent styryl dye, RH421, were performed to analyze the inhibitory effect on partial reactions of the pump cycle. ${ }^{2} \mathrm{Na}, \mathrm{K}$-ATPase was prepared from the outer medulla of rabbit kidneys. The buffer contained $30 \mathrm{mM}$ imidazole, $5 \mathrm{mM} \mathrm{MgSO} 4,1 \mathrm{mM}$ EDTA (pH 6.95), $100 \mathrm{nM} \mathrm{RH421,} \mathrm{and} 3 \mu \mathrm{g} / \mathrm{mL}$ $\mathrm{Na}, \mathrm{K}$-ATPase (at $20 \pm 0.5^{\circ} \mathrm{C}$ ). Specific fluorescence levels could be assigned to defined states in the pump cycle of the Na,K-ATPase. ${ }^{3}$

With RH421, the effects of MCS factors on various partial reactions of the $\mathrm{Na}, \mathrm{K}$ ATPase were studied (FIG. 1A). When adding MCS factors in states $\mathrm{E}_{1}, \mathrm{Na}_{3} \mathrm{E}_{1}$, and $\mathrm{P}-\mathrm{E}_{2}$, subsequent fluorescence levels were reduced in amplitude, but fluorescence changes displayed the same directions (FIG. 1B). Although no enzymatic activity remained in the presence of $7 \mu \mathrm{M} \mathrm{MCS}, \mathrm{Na}^{+}$and ATP additions still induced fluorescence changes. This suggests that the $\mathrm{Na}, \mathrm{K}-\mathrm{ATPase}$ can still bind $\mathrm{Na}^{+}$and be phosphorylated by ATP. $\mathrm{K}^{+}$was able to induce fluorescence changes from all states. The only case when fluorescence did not change dramatically was when adding MCS factors to $E_{2}\left(K_{2}\right)$.

In the presence of $1 \mathrm{mM} \mathrm{K}^{+}$, saturating amounts of $\mathrm{Na}^{+}$are able to shift the enzyme into state $\mathrm{Na}_{3} \mathrm{E}_{1}$, and subsequent addition of ATP will induce phosphorylation and produce a fluorescence increase (FIG. 1C). Adding MCS factors to $\mathrm{E}_{2}\left(\mathrm{~K}_{2}\right)$ (FIG. 1D) again reduces the $\mathrm{Na}^{+}$signal amplitude, but also decelerates significantly $\mathrm{Na}^{+}$-binding kinetics. Subsequent addition of ATP indicates that, in the presence of MCS factors, the enzyme is not effectively being phosphorylated anymore.

Address for correspondence: Robert Stimac, Department of Biology, University of Konstanz, Fach M635, 78457 Konstanz, Germany. Voice: $+49-7531-882901$; fax: $+49-7531-883183$.

Robert.Stimac@uni-konstanz.de 

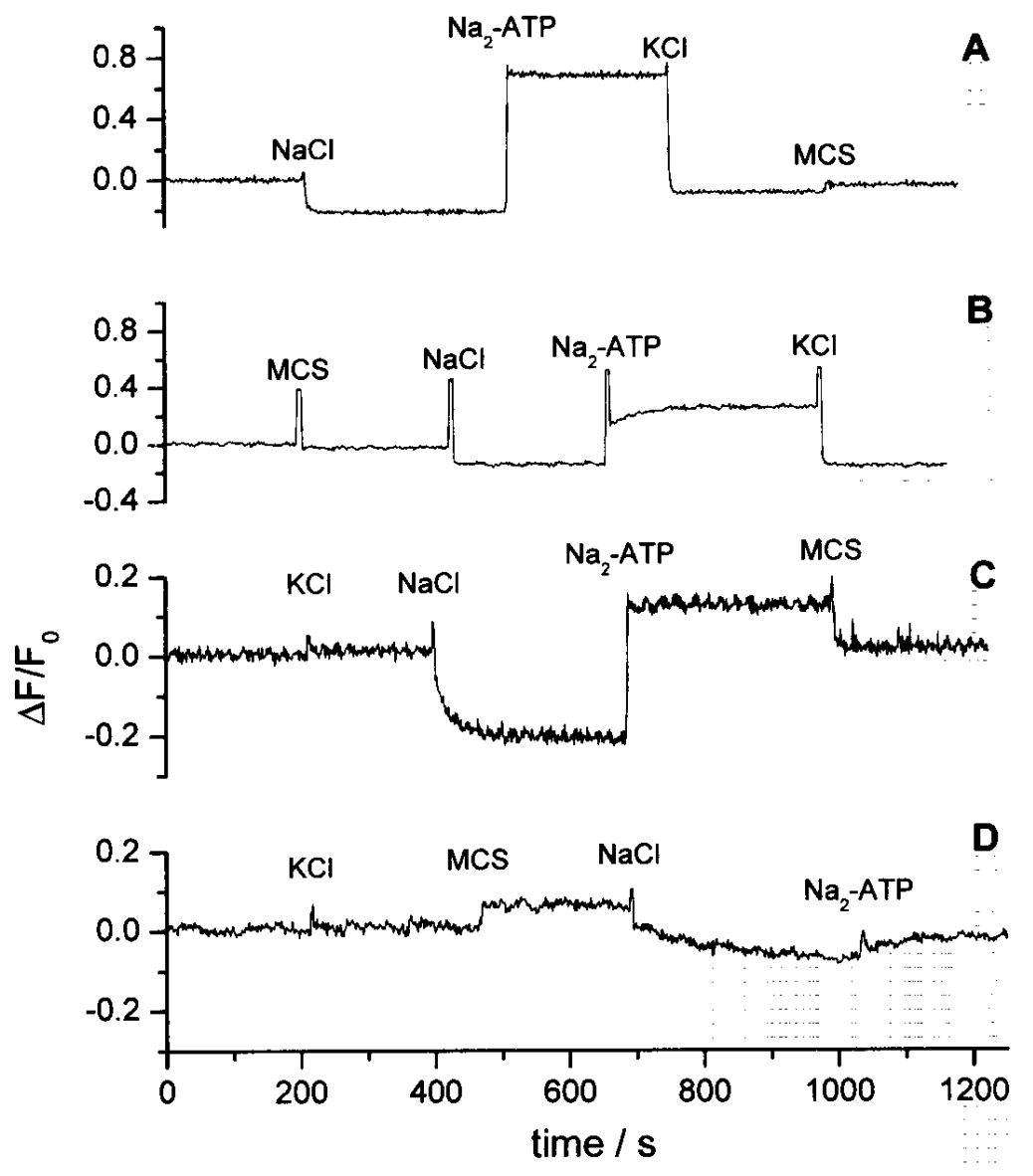

FIGURE 1. Substrate-induced partial reactions as detected by RH421 fluorescence experiments. Substrate additions are indicated: $50 \mathrm{mM} \mathrm{NaCl}, 100 \mu \mathrm{M} \mathrm{Na} 2 \mathrm{ATP}, 20 \mathrm{mM} \mathrm{KCl}$ (A, B) or $1 \mathrm{mM} \mathrm{KCl} \mathrm{(C,} \mathrm{D),} 7 \mu \mathrm{M}$ MCS factors, and $50 \mu \mathrm{M}$ ouabain. The effect of the MCS factors on the following protein conformation is shown: (A) $E_{2}\left(K_{2}\right)$, (B) $E_{1}$, (C) $P-E_{2} / E_{2}\left(K_{2}\right)$, and (D) $E_{2}\left(K_{2}\right)$.

From inhibition experiments with MCS factors and ouabain simultaneously, it was concluded that both inhibitors do not compete for the same binding site and that MCS factors inhibit the Na,K-ATPase reversibly in a state that follows in the PostAlbers cycle the ouabain-inhibited state.

In summary, MCS factors inhibit the Na,K-ATPase in an $\mathrm{E}_{2}\left(\mathrm{~K}_{2}\right)$-like state in which enzyme phosphorylation is prevented. They do not compete with ouabain for the same binding site.

\section{ACKNOWLEDGMENTS}

This work was supported by the Deutsche Forschungsgemeinschaft (AP 45/8). 


\section{REFERENCES}

1. KEREK, F. 2000. The structure of the digitalislike and natriuretic factors identified as macrocyclic derivatives of the inorganic carbon suboxide. Hypertens. Res. 23(suppl.): S33-S38.

2. Heyse, S. et al. 1994. Partial reactions of the Na,K-ATPase: determination of rate constants. J. Gen. Physiol. 104: 197-240.

3. SchneEberger, A. \& H-J. Apell. 1999. Ion selectivity of the cytoplasmic binding sites of the Na,K-ATPase: I. Sodium binding is associated with a conformational rearrangement. J. Membr. Biol. 168: 221-228. 